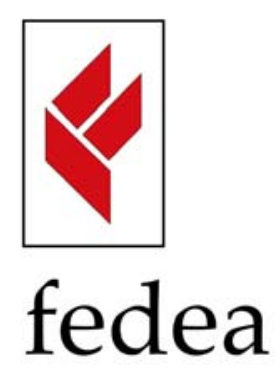

Fundación de

Estudios de

Economía Aplicada

\title{
Production Subcontracting and Location ${ }^{*}$ \\ by \\ Adelheid Holl $^{* *}$ \\ DOCUMENTO DE TRABAJO 2007-17
}

\author{
June 2007 \\ SERIE Economía Regional \\ CÁTEDRA Fedea - Caja Madrid
}

* $\quad$ Acknowledgements - Financial support from the ESRC, grant T026271031 and grant RES-000-22-0056, as well as from the Social and Economic Council of the Autonomous Community of Madrid is gratefully acknowledged. For helpful comments on earlier drafts, I am grateful to the anonymous referees as well as participants at the 50th North American Meetings of the Regional Science Association International, Philadelphia, November 2003.

** FEDEA (Foundation for Applied Economics Studies). c/ Jorge Juan, 46, 28001 Madrid, Spain. Tel.: +34 914359 020; Fax: + 34915 779 575. E-mail address: a.holl@fedea.es Los Documentos de Trabajo se distribuyen gratuitamente a las Universidades e Instituciones de Investigación que lo solicitan. No obstante están disponibles en texto completo a través de Internet: $h t t p: / / w w w . f e d e a . e s$.

These Working Paper are distributed free of charge to University Department and other Research Centres. They are also available through Internet: $h t t p: / / w w w . f e d e a . e s$. 
Depósito Legal: M-29748-2007 


\begin{abstract}
Using data from a panel of Spanish manufacturing firms, I examine factors that explain firms' production subcontracting decisions and test whether there is any evidence that production subcontracting is facilitated in areas typically associated with higher agglomeration economies. The results show that location matters. Firms in industry agglomerations are more likely to subcontract production activities. While in general, larger and older firms as well as high wage firms show a greater probability for production subcontracting, industry agglomeration particularly facilitates subcontracting for smaller and lower wage firms and it allows firms to respond to a greater degree to expansive demand conditions by taking advantage of subcontracting.
\end{abstract}

JEL classification: D21, L23, L60, R3

Key words: Production subcontracting, agglomeration economies 


\section{Introduction}

Subcontracting is an increasingly popular competitive strategy for production organisation. ${ }^{1}$ The literature emphasises subcontracting as a strategy for achieving flexible and lean production that allows firms to avoid the rigidities related to vertically integrated production structures. Subcontracting is seen to offer potential advantages in relation to wage and cost savings, protection from market risks that stem from unpredictable variations in demand, and an ability to specialise in operations where firms have a competitive edge while building on expert-knowledge through the subcontracting arrangement (Abraham and Taylor, 1996). Recent empirical studies also suggest that subcontracting is related to improved firm performance (Girma and Görg, 2004; Morrison and Yasar, 2004) $)^{2}$ as well as being a source of knowledge transfer (Deardorff and Djankov, 2000; Helsley and Strange, 2002).

From an urban and regional economic perspective subcontracting has become a key issue for both policy makers and researchers. An important question is how the characteristics of the local environment affect the organisation of production, and how in turn industrial organisation affects the benefits of agglomeration (Chinitz, 1961; Rosenthal and Strange, 2003, 2004). Marshall (1920) shows that agglomeration allows for the sharing of inputs and facilitates the emergence of specialised intermediate input producers. Similarly, Stigler (1951) argues that increasing local market size leads to greater vertical disintegration. This literature suggests that agglomeration can encourage the rise of subcontracting arrangements. Few studies have, however, specifically addressed the importance of location factors in affecting firms' subcontracting decision. The closest related study is Ono (2007) who estimates the effect of market thickness on the likelihood of outsourcing business services. Using cross section data for U.S manufacturing firms, Ono finds that plants in bigger cities are more likely to outsource services.

This paper extends upon the literature on subcontracting and agglomeration in several ways. First, I examine the subcontracting decision of Spanish manufacturing firms using panel data. By applying a version of Chamberlain's (1984) correlated random effects model, the estimation strategy differs substantially from the previous literature on firms' subcontracting decision. Estimations control for unobserved heterogeneity and take into account that firms plausibly choose locations on unobservables, which in turn, could be

\footnotetext{
${ }^{1}$ The literature frequently uses the term subcontracting as well as outsourcing interchangeably.

${ }^{2}$ Görzig and Stephan (2002) find for German manufacturing firms that material and intermediate input subcontracting positively impacts firm performance, but no consistent effect is found for service subcontracting. Other studies reporting a positive relationship between subcontracting and firm performance are, for example, Urata and Kawai (2002) for Japanese firms and Mazzola and Bruni (2000) for a sample of southern Italian small firms.
} 
related to the subcontracting decision, causing correlation of explanatory variables and unobserved firm-specific effects. With the exception of Ono (2007) previous studies on the determinants of subcontracting have not considered the potential simultaneous determination of firms' location and subcontracting decision.

This analysis also differs from previous research in that it allows the impact of location to depend on firms' structural characteristics. Finally, I focus on production subcontracting. The literature has emphasised the role of proximity and thus local markets for services due to their special need for faceto-face contacts, but how the local economy affects decisions on production subcontracting has been much less studied. Agglomerations can sustain a wider variety and a greater amount of material input suppliers which may facilitate production subcontracting through lower search costs and better matching between subcontracting clients and suppliers, a more competitive subcontracting sector, as well as savings in the cost and time to transport subcontracted inputs. I find evidence that location matters. Firms in industry agglomerations are more likely to subcontract production activities, even when controlling for firmspecific unobserved heterogeneity and allowing for correlated random effects. Industry agglomeration particularly facilitates subcontracting for smaller and lower wage firms, and it allows firms to respond to a greater degree to volatility of demand by taking advantage of subcontracting.

In the next Section, I review the relevant literature on the determinants of subcontracting. In Section 3, I first describe the data set used for the empirical analysis and then present some descriptive statistics on the subcontracting behaviour of the sample of Spanish manufacturing firms covering the period between 1990 and 1999. I then present the econometric model and discuss the subcontracting determinants tested in this paper. Section 4 presents the results of the empirical estimation, and Section 5 concludes.

\section{The determinants of subcontracting}

Following Coase's (1937) seminal work activities would be outsourced where the perceived costs of using the market were less than that of undertaking the activity in-house. From this point of view, the decision to subcontract constitutes primarily a trade-off between the costs and benefits associated with each alternative. The factors that influence the trade-off can be grouped into production cost factors and transaction cost factors. Location characteristics 
related to the benefits of agglomeration constitute a third group of factors by affecting both production costs as well as transaction costs. ${ }^{3}$

\section{Production cost factors}

Subcontracting can imply production cost savings relative to in-house production in three principal ways (Abraham and Taylor, 1996). First, through labour cost savings. Higher wage firms may try to cut labour costs by contracting out part of their activities to lower wage producers. This is a way to segment the labour force and high wage firms that are unable to pursue different wage strategies internally may take advantage and subcontract unskilled labour intensive production tasks.

Second, fluctuations in the firm's product market may favour subcontracting. Firms may try to smooth the work load of their core workforce by contracting out tasks during peaks of demand. This type of production subcontracting relates to what is also known as capacity subcontracting. In this case the contractors are used for a buffering role.

Third, production costs savings can be achieved where outside suppliers benefit from economies of scale or specialised knowledge. This relates to what has also been termed specialisation subcontracting. It is most likely where individual production processes require different levels of minimum efficient scale and where, for example, the minimum efficient scale of one part exceeds the firm's demands for this part.

\section{Transaction costs}

Transaction cost approaches building on the seminal work of Williamson $(1975,1985)$ argue that the choice between in-house production and subcontracting is not only a matter of production cost differences. The subcontracting decision is also determined by the cost of setting up and maintaining a subcontracting relationship. Transaction costs arise from the need of asset specific investment (Roodhooft and Warlop, 1999) and the specification, monitoring, and enforcement of contracts (Grossman and Hart, 1986). Where the subcontracting relation requires firm-specific investments, tasks are more likely to be integrated. The same is the case if contracts are likely to be imperfect, e.g. where not all attributes of the inputs are verifiable by third parties, and where contracts are therefore difficult to enforce.

\footnotetext{
${ }^{3}$ See, for example, Helsley and Strange (2007) who link agglomeration economies and transaction costs in the context of integrated versus disintegrated production.
} 
Grossman and Helpman (2002 and 2005) furthermore emphasise that firms choosing to subcontract have to first search for suitable partners. They show in a general equilibrium model that with costly search, subcontracting is more likely to be viable where firms find more potential subcontracting partners. Firms' propensity to subcontract thus can depend on the characteristics of the local economy.

\section{The Role of Location}

In Grossman and Helpman (2002 and 2005) the size and structure of the local economy determines firms' opportunities for subcontracting through the cost for searching for suitable subcontracting partners. Lower search costs are one aspect of positive agglomeration effects. This is, however, not the only way location characteristics can impact on firms' subcontracting decision. Clustering of potential providers can also influence the price for the subcontracted activity. Ono (2007) argues in the context of service outsourcing that bigger markets attract more providers, which, in turn, induces greater competition. This can lower the price for the subcontracted activity and increases the propensity for subcontracting. Thus firms in larger local markets should enjoy greater opportunities for subcontracting. Venables (1996) shows in general equilibrium model in the spirit of the new economic geography literature how direct inputoutput linkages (vertical linkages) between industries are a reason why firms choose location proximate to each other. Locating close to downstream industries provides a larger market (demand linkage) and being close to upstream industries saves transport costs on intermediate inputs (cost linkage). For firms' subcontracting decision, this implies that proximity can also lead to savings in transportation costs for inputs that have to be transported between the subcontractor and the client firm. With the ongoing restructuring of manufacturing towards integrated production, transport and communication processes such as 'just-in-time' production organisation or 'quick response' delivery strategies, firms are also becoming increasingly time sensitive. Proximity, can allow important time savings in transportations supporting the subcontracting linkages and it can provide the flexibility required for modern production organisation. Finally, subcontracting relations often involve direct collaborations between design teams of client and supplier which are also facilitated with proximity.

The literature on the spatial dynamics of flexible specialised production networks identifies subcontracting as a key characteristic of industrial districts and emphasises the importance of geographical proximity in establishing interfirm linkages such as subcontracting relations (Scott, 1987; 1988; 1993). SuarezVilla and Rama (1996) and Rama et al. (2003) in their analysis of the electronics 
industry in Madrid provide good examples of how clustering of firms facilitates subcontracting.

However, how local economic conditions affect firms' subcontracting probability has received relatively little attention in the empirical literature on the determinants of subcontracting. Abraham and Taylor (1996) study subcontracting of business services of U.S. industrial establishments. Including a dummy variable for metropolitan locations they find a positive effect for accounting and computer services outsourcing, but not for other business services. Love and Roper (2001) find mixed results for the effect of regional population density and regional government $R \& D$ spending on the outsourcing decision in the innovation process for UK and German manufacturing plants. Merino and Rodríguez (2005) also find mixed results for the effect of city location and the number of service providers in the same region for service subcontracting in Spanish manufacturing firms. Ono (2007) finds a significant positive relationship between the local market thickness of services and the probability of business service outsourcing by U.S. manufacturing firms.

The few studies that have taken location factors into account in analysing the determinants of subcontracting have generally focused on service outsourcing. An exception is Taymaz and Kilicaslan (2005) which studies subcontracting intensity among firms in the Turkish textile and engineering industries. Findings show a strong positive effect for the number of same-sector firms in the same province. However, potential simultaneity in the location and subcontracting decision is not taken into account, and the agglomeration effect could therefore be estimated with bias.

\section{Data and model specification}

\subsection{Data}

The Encuesta sobre Estrategias Empresariales (ESEE) published by the Fundación Empresa Pública provides a wide range of information on a sample of 3,195 Spanish manufacturing firms. The survey is undertaken annually since 1990 and constitutes an unbalanced panel. It is approximately representative of Spanish manufacturing firms with more than 10 employees. In 1990, all firms with more than 200 employees (large firms) were asked to participate in the survey, and the rate of participation reached around 70 percent. Firms that employed between 10 and 200 employees (small firms) were chosen according to a random sampling scheme. In subsequent years the initial selection criteria have been maintained by incorporating newly created firms selected with the same sampling criteria as in the base year (see Ministry of Industry, 1992; and 
Fariñas and Jaumandreu, 1999 for more details). The final sample for this analysis consists of an unbalanced panel of 2,735 manufacturing firms for the period 1990 to $1999 .{ }^{4}$ Details on the composition of the panel in terms of observations per firm can be found in Appendix Table A1.

The survey includes information on firms' production subcontracting behaviour, where subcontracting refers to a contractual relationship in which the firm commissions a third party company to produce products, parts, or components made to the firm's specifications. ${ }^{5}$ Location information for the surveyed firms is available at the geographical level of Autonomous Communities (NUTS 2). ${ }^{6}$

Tables 1 to 3 provide some basic descriptive statistics on the subcontracting propensity of Spanish manufacturing firms. At the beginning of the 1990s about 36 percent of all Spanish manufacturing firms in the sample engaged in production subcontracting and the average share of subcontracted input in total purchased industry input was about 7.5 percent (Table 1). Note that both subcontracting propensity and intensity is higher among larger firms. Over the period of the 1990's subcontracting has become more common among Spanish manufacturing firms in all three size classes. This reflects a trend that has been widely documented for other countries (see, for example, Abraham and Taylor, 1996; European Commission, 1997; Shy and Stenabacka, 2003). Table 2 shows that there are large differences between the extent of subcontracting across sectors. ${ }^{7}$ Sectors that most extensively use production subcontracting are the machinery, office and electrical equipment, transport equipment and other manufacturing sectors ${ }^{8}$, while production subcontracting is less common in the metal and mineral products industry as well as in the food sectors.

\footnotetext{
${ }^{4}$ Only firms that report full information on all relevant variables are included. The mean number of years that firms remained in the panel is 5.9 years. Out of the 2,735 firms, 1,679 are in the panel since 1990 of which 733 remained until 1999. Over this period, there were 1,255 firms exiting the panel while 1,056 where newly incorporated into the panel.

${ }^{5}$ Note that when a firm purchases non-customized products, parts or components this is not regarded as subcontracting. In the case of intermediate inputs or components, the distinction between subcontracting and purchase of ready-made parts and components can be blurred as pointed out by Holmes (1986) particularly in the case of the automotive and electronics industry.

${ }^{6}$ An interesting question concerns the location of the subcontracting client firm in relation to the subcontracting parent firm. Unfortunately, the ESEE data does not permit to explicitly address this question as it only records whether firms subcontract but not whether they have worked as subcontractors.

${ }^{7}$ Note that while overall, the general trend of increasing subcontracting is reflected, the figures at the sectoral level are influenced by the changing number of firms responding to the survey, particularly, in the case of sectors with only a small number of respondents.

${ }^{8}$ Other manufacturing includes: Manufacture of currencies and medals, musical articles, jewellery, articles of silver and gold craft, musical instruments, photography laboratories, manufacture of games and toys, and sports articles.
} 
Table 3 reflects the geographical pattern of subcontracting. The average propensity for subcontracting and the subcontracting intensity in the peripheral regions is considerably lower than in the areas that concentrate most economic activity. Increased subcontracting in industry agglomerations is, for example, consistent with Holmes (1999) who finds that purchased-input intensity is higher where an industry is concentrated. If there are agglomeration benefits then firms that subcontract would be expected to be concentrated in economic agglomerations, but this by itself is not evidence of a positive agglomeration effect. To identify the effects of agglomeration externalities on production subcontracting it is necessary to control for other factors that affect firms' subcontracting decision.

\subsection{Model specification}

Given the interest in this paper on the subcontracting decision, estimations focus on the probability that a firm subcontracts. Let subcontracting $y_{i t}$ of firm $i$ $=1,2, \ldots, N$ in periods $t=1,2, \ldots . T$ be captured by a binary choice model

$$
y_{i t}=\left\{\begin{array}{c}
1 \text { if } y_{i t}^{*} \geq 0 \\
0 \text { else }
\end{array}\right.
$$

where the latent variable $y_{i t}^{*}$ representing firm i's underlying propensity to subcontract in period $t$ is a linear function of observable firm specific characteristics $c_{i t}$ and a region specific characteristic related to agglomeration economies $a_{r t}$

$$
y_{i t}^{*}=c_{i t} \beta_{1}+a_{r t} \beta_{2}+v_{i t}
$$

and where $\beta=\left(\beta_{1}^{\prime}, \beta_{2}^{\prime}\right)^{\prime}$ denotes the vector of unknown parameters associated with $x_{i t}=\left(c_{i t}, a_{r t}\right)$. The term $v_{i t}$ captures the effects of unobserved factors and is assumed to be i.i.d. normal.

The pooled cross section probit model does not take advantage of the panel nature of the data and ignores unobserved firm level heterogeneity. Assuming that unobservable firm-specific heterogeneity is time-invariant, in the random effects probit model the error term $v_{i t}$ is decomposed as

$$
v_{i t}=u_{i}+\varepsilon_{i t}
$$

where $u_{i}$ denotes the firm-specific unobservable effect and $\varepsilon_{i t}$ is the usual random error. 
The random effects (RE) probit model requires that $u_{i}$ is random and uncorrelated with the explanatory variables. This assumption will not hold if unobservable characteristics of firms affect both the choice of location as well as the probability of subcontracting.

For example, $u_{i}$ could reflect management ability that influences both location and subcontracting decisions. In a new economic geography framework, Baldwin and Okubo (2006) show how location in the largest markets is most attractive for the most productive firms and how this can overestimate agglomeration economies when not accounted for in empirical studies. Nocke (2006), shows in a theoretical model how more efficient entrepreneurs self select into larger markets. It is also plausible that more efficient entrepreneurs are those that concentrate on core functions and subcontract other activities to external suppliers. Such firms could, for example, show greater ability in managing subcontracting relations.

Management strategy could further relate to both location and subcontracting decisions. Firms that best carry out all production activities inhouse and with no intention of engaging in production subcontracting would naturally not take into account locational opportunities for subcontracting in their location choice. In fact, vertically integrated firms could prefer more peripheral regions to take advantage of lower labour and land costs. In contrast, firms that do not have the necessary capacity to efficiently carry out all production processes in-house could prefer locations in agglomerations of economic activity where they can find a greater amount of potential subcontracting partners $\left(\right.$ Ono, 2007) ${ }^{9}$.

This simultaneous determination not only means that location variables will be correlated with unobservables, but also that other firm-specific variables, related to unobservables and linked to location, will be correlated with the unobservable firm-specific term. To address this problem, I employ a version of Chamberlain's random effects probit model (CRE) which parametrically specifies the individual unobserved heterogeneity allowing for correlation with the observed variables (Chamberlain, 1984). ${ }^{10}$ Assuming that $u_{i}$ is related to the time averages $\bar{x}_{i}$ of time varying variables $x_{i t}$ and that it follows a conditional normal distribution,

$$
u_{i} \mid x_{i 1}, \ldots, x_{i T} \sim N\left(\varphi+\bar{x}_{i} \xi, \sigma_{\eta}^{2}\right)
$$

\footnotetext{
${ }^{9}$ With cross section data, Ono (2007) deals with this problem by estimating fixed effects logit models where the effect of market thickness on service outsourcing is identified through exploring the variation in outsourcing across different types of services.

${ }^{10}$ I would like to thank one anonymous referee for proposing this approach.
} 
where $\sigma_{\eta}^{2}$ is the variance of $\eta_{i}$ in the regression $u_{i}=\varphi+\bar{x}_{i} \xi+\eta_{i}$ and constitutes the conditional variance of $u_{i}$ and $\operatorname{cov}\left(\eta_{i}, \varepsilon_{i t}\right)=0$. Given this specification the model can be written as

$$
P\left(y_{i t}=1 \mid x_{i 1}, \ldots, x_{i T}, u_{i}\right)=\Phi\left(\theta\left(x_{i t} \beta+\varphi+\bar{x}_{i} \xi\right)\right)
$$

where $\theta=\left(1+\sigma_{\eta}^{2}\right)^{-1 / 2}$. Estimation of (5) is straightforward by including additional regressors $\bar{x}_{i}$ in the random effects probit model. Identification is based on variations around means assuming that heterogeneity is correlated with the permanent component but not with the transitory part. Wooldridge (2002) provides a detailed discussion of this model.

\subsection{Independent variables}

As in previous studies, the following firm characteristics are included in estimations: wage costs (WAGE), firm size (SIZE), firm age (AGE), foreign ownership (FORD), and demand fluctuations (FLUCT). These variables are intended to capture the diverse firm specific production and transaction cost elements in influencing firms' subcontracting decision.

WAGE is defined by the log average annual wage rate per employee. If firms subcontract to reduce labour cost, higher wage firms should show a greater propensity for subcontracting. The SIZE variable is the log of employees. Based on the arguments relating to economies of scale as determinants for subcontracting, this variable should show a negative sign. Abraham and Taylor (1996) argue that it may not be optimal for smaller companies to carry out all steps in the production process, but they can improve efficiency by subcontracting parts to specialised producers that enjoy scale economies. Small companies may therefore be more likely to contract out work for reasons related to specialisation subcontracting where the firm cannot maintain economically specialised equipment or skills in-house. The empirical results reported in Abraham and Taylor (1996) largely support this line of argumentation for the subcontracting of business services among U.S. manufacturing firms. It is, however, in contrast to findings by others. Kelly and Harrison's (1990) study the differences between large and small U.S firms in the degree to which they undertake production subcontracting and find that the larger the firm, the greater the probability of production subcontracting. Similar results of a positive relationship between firm size and subcontracting are found in Ono (2003) for the outsourcing of services. A possible explanation is that the potential benefits of taking advantage of economies of scale of specialised producers are limited where the subcontracting relation requires specific investment. Such a positive relationship further indicates some element of market power, suggesting that 
transaction costs and search costs related to establishing, monitoring, and enforcing a subcontracting relationship would be less of an impediment for larger firms.

Previous studies also suggest that more mature firms start concentrating on their core activities and thus can show a higher propensity for subcontracting. This relates to the plant-life cycle argument. At the same time, there can also be a 'learning effect' at work where firms learn about the quality and reliability of potential subcontractors with age. This makes it easier for longer established firms to find suitable subcontractors (Ono, 2003). I include the variable AGE measured as the log of years the firm is in business. Görg and Ruane (2000) further suggest that firms with foreign ownership have lower subcontracting probabilities. The reasons are related to the character of branch plants. I include the variable FORD, which takes on value 1 if the firm has foreign ownership participation. To control for demand variations, I include the dummy variable FLUCT which takes on the value of 1 where firm $i$ 's main market was expansive during the year of reference. ${ }^{11}$ This measures firms' surrounding demand environments and is intended to pick up general market volatility. Given that under expansive market evolution firms are more likely to face internal capacity limits, this variable is expected to have a positive impact on the subcontracting decision.

To test whether firms' subcontracting decision is related to locational effects, I include IND, which is the log of the total regional industrial employment density in year $t$. IND reflects clustering of economic activity and accounts for the effects of agglomeration economies. Empirical studies of agglomeration economies have also used the size of the urban or regional economy (usually proxied by total employment or total population) to test for agglomeration economies. However, Ciccone and Hall (1996) argue that density of economic activity rather than size is the source of agglomeration economies. Employment density has been used, among others, in Combes (2000) to test for effects on employment growth among local areas in France, and in Ciccone (2002) to test for the effect of agglomeration on productivity levels across NUTS-3 regions in five European countries. Table A2 in the Appendix provides mean background characteristics of those firms that subcontract and those who do not across areas of high and low industry density, while Table A3 presents a correlation matrix of the independent variables.

According to Marshall (1920) geographic clustering of firms provides an environment for the emergence of a host of specialised producers. The literature discussed suggests that firms in areas with more suitable subcontractors located

\footnotetext{
${ }^{11}$ FLUCT is based on information provided by firms in the ESEE regarding the evolution of their product markets.
} 
nearby should show a higher propensity for subcontracting, because they face lower search costs, lower subcontracting prices due to higher competition among subcontractors, and savings in transportation costs due to better access and easier contact between subcontractor and client firm. This suggests that location characteristics determine subcontracting primarily through production and transaction costs, rather than having an independent role. ${ }^{12}$ Thus, the effect of location $\mathrm{a}_{\mathrm{rt}}$ may depend on the firm specific characteristics $c_{i t}$ intended to capture the diverse firm specific production and transaction cost influences on firms' subcontracting decision. For example, small firms can find subcontracting less difficult in industry agglomerations. To allow for this, estimations include interactions between the firm characteristics and the industry density variable.

\section{Estimation results}

Estimation results are presented in Table 4. All estimations include unreported annual year dummies as well as industry dummy variables. As a starting point and benchmark, the pooled cross-section probit and the random effects (RE) panel probit estimates are reported in column (1) to (4) of Table 4 to illustrate how the omission of unobserved heterogeneity and its potential correlation with other explanatory variables affects the estimated coefficients. In column (5) estimates of the preferred Chamberlain random effects probit (CRE) model are presented where random effects are allowed to be correlated with firm characteristics and the agglomeration proxy IND. As shown by the likelihood ratio test, estimations include a significant random effects component. Testing for joint significance of the mean coefficients yields a chi-squared statistic significant at the 1 percent level indicating that there is correlation between explanatory variables and the unobservable heterogeneity term. In addition, a Hausman test also favours the CRE model, so that the RE probit can be rejected in favour of the CRE model. ${ }^{13}$

Starting with the firm specific characteristics, coefficients in the cross section estimates of column (1) to (3) show high levels of significance and are generally in line with prior expectations. Higher wages are positively related to the production subcontracting decision. This positive coefficient of WAGE is robust to controls for unobserved heterogeneity and correlated random effects.

The positive and statistically significant coefficient of firm size in all five model specifications also indicates that large firms have a higher propensity to subcontract part of their production activities. This is, however, in contrast to Abraham and Taylor's (1996) argument of economies of scale motives for

\footnotetext{
${ }^{12}$ I would like to thank one anonymous referee for drawing attention to this point.

${ }^{13}$ Estimations based on a balanced panel yield qualitatively similar, although less significant results.
} 
subcontracting. It provides more support for the transaction cost argument where larger firms have greater capacity in establishing and managing subcontracting relationships. To further test for the economies of scale motive, the variable SMALLP is included in column (2). This variable indicates whether firms predominantly produce in small batches and this may better capture limited possibilities to achieve economies of scale in all production processes. The cross section and random effects probit results support this view and indicate that small-batch production may actually better capture the economies of scale motive than the firm size variable. However, in the correlated random effects model SMALLP is no longer significant.

Concerning the age of the company, the estimation results show a positive and statistically significant relationship in all five models between the probability of subcontracting and a firm's maturity as indicated by the AGE coefficient.

Cross sectional results further suggest that foreign ownership (FORD) reduces a firm's subcontracting probability, whereas the panel data results in column (4) and (5) indicate that foreign ownership does not have a significant adverse impact on subcontracting. The proxy for demand fluctuations FLUCT is also only statistically significant and of the expected sign in the cross section estimations of column (1) and (2). The coefficients that are mostly affected by the change in estimation technique are the three firms specific dummy variables (FLUCT, FORD, and SMALLP). This is possibly due to limited time-series variation leading to imprecise estimates of the parameters and a strong correlation with unobservable heterogeneity.

Turning to the agglomeration variable, there is evidence of the importance of location characteristics for the probability that firms engage in production subcontracting. Industry density (IND) in a region is statistically significant and shows the expected positive effect on firm's subcontracting decision. Most importantly to this analysis, industry density continues to shows a positive and significant coefficient on subcontracting even after controlling for firm specific unobserved heterogeneity and allowing for correlated random effects. ${ }^{14}$

To investigate whether firm-specific determinants of subcontracting condition the influence of industry density, the firm-specific explanatory variables are interacted with IND in column (3) to (5). Concentrating on the

\footnotetext{
${ }^{14}$ Results are also robust to other definitions of agglomeration. For instance, qualitatively similar results are obtained when the agglomeration proxy is based on employment density in other sectors or on the density of public capital stock related to transport infrastructure. In contrast, same sector agglomeration proxies do not yield significant results, suggesting that, for industry in general, intersectoral subcontracting might be more important than subcontracting to firms in the same sector.
} 
preferred CRE results, the interaction terms are jointly significant indicating that the role of industry density is influenced by the firm-specific determinants of subcontracting. Three of the interaction coefficients are individually statistically significant. Both the size and wage coefficients are reduced with increasing industry density, indicating that smaller firms and lower wage firms can find subcontracting less difficult in industrial agglomerations. At the same time, the interaction coefficient for expansive demand evolution is positive, indicating that firms in industry agglomerations respond to a greater degree to expansive market conditions by taking advantage of subcontracting.

In any non-linear model, coefficients are not equal to marginal effects. Marginal effects vary depending on the values of the conditioning variables. Through the nonlinear form, effects depend on the values of all other independent variables. With explicit interaction terms, marginal effects additionally depend directly on the values of the variables with which they are interacted. In the CRE probit model, the calculation of marginal effects furthermore has to take into account the correlation between included variables and the individual firm specific unobserved effect $u_{i}$. Following Chamberlain (1984), consistent marginal effects can be calculated as the mean effect on the subcontracting probability for a randomly chosen firm for changing $x_{i t}$ from $\dot{x}$ to $\ddot{x}$, by

$$
\frac{1}{N} \sum_{i=1}^{N} \frac{1}{T_{i}} \sum_{t=1}^{T_{i}}\left\{\Phi\left[\theta\left(\ddot{x}_{i t} \beta+\varphi+\bar{x}_{i} \xi\right)\right]-\Phi\left[\theta\left(\dot{x}_{i t} \beta+\varphi+\bar{x}_{i} \xi\right)\right]\right\},
$$

where parameters are replaced by their estimates and $T_{i}$ refers to the number of periods firm $i$ appears in the panel. I compute marginal effects for interactions with statistically significant coefficients in the preferred CRE model. Figure 1, shows how the relationship between subcontracting and industry density differs at various values of firm size. ${ }^{15}$ Consistent with the negative coefficient of the interaction term, the marginal effects of industry density is much bigger for smaller firms, but becomes almost negligible for the largest firms. It makes sense that particularly small firms benefit from industry agglomeration. This is also consistent with much of the agglomeration and industrial districts literature. Figure 2 presents the marginal effect of industry density at different wage levels. For the lower 20 percentile, the effect of industry density is almost double compared to the upper 20 percentile. Finally, for firms with expansive market conditions, industry density increases subcontracting probability by $0.7 \%$ compared to $0.5 \%$ for firms with stable or recessive markets.

\footnotetext{
${ }^{15}$ Estimates are based on a 10\% increase in industry density from the average value.
} 


\section{Conclusions}

This study has aimed to contribute to a better understanding of firms' production subcontracting behaviour by focusing on the role of location. Location can influence subcontracting decisions through agglomeration economies. Industry agglomerations can sustain a wider variety and a greater amount of material input suppliers which may facilitate production subcontracting through lower search costs, better matching between subcontracting clients and suppliers, a more competitive subcontracting sector, as well as savings in transportation costs and time of subcontracted inputs.

A quantitative view of the determinants of subcontracting relations is essential for a better understanding of the microfoundations of the location and spatial organisation of economic activity. The results in this paper show that a number of firm characteristics are important in determining the propensity to engage in production subcontracting, but I also find evidence for agglomeration effects. Firms in industry agglomerations are more likely to subcontract, suggesting that areas with a larger industrial basis provide in general better opportunities for production subcontracting. This result is robust to alternative estimation strategies that control for unobserved firm-specific effects as well as the fact that firms are likely to self-select into locations on the basis of unobservables that may influence at the same time subcontracting decisions, causing correlation of explanatory variables and unobserved firm-specific effects. Interaction between firm characteristics and the agglomeration proxy further indicate that industry agglomeration makes subcontracting also more attractive for smaller and lower wage firms, and it allows firms to respond to a greater degree to volatility of demand by taking advantage of subcontracting. These results show that firms' external environment influences production organisation but that different types of firms respond differently to their environment.

The results presented in this paper highlight that there is an important dimension of industrial organisation to agglomeration economies. This is important given that there is considerable theoretical and policy interest in how clustering of firms facilitates vertical disintegration and inter-firm linkages and how in turn industrial organisation affects the benefits of agglomeration. 


\section{References:}

Abraham, K. G. and S. K. Taylor, 1996, Firms' Use of Outside Contractors: Theory and Evidence, Journal of Labour Economics 14 (3), 394-424.

Baldwin, R.E. and T. Okubo, 2006, Heterogeneous firms, agglomeration and economic geography: spatial selection and spatial sorting, Journal of Economic Geography 6 (3), 232-346.

Chamberlain, G., 1984, Panel Data, in Handbook of Econometrics, vol. 2, ed. Z. Griliches and M. Intriligator. Amsterdam: North Holland, 1247-1318.

Chinitz B., 1961, Contrast in Agglomeration: New York and Pittsburgh, American Economic Review 51 (2), 279-289.

Ciccone, A. and R. E. Hall, 1996, Productivity and the Density of Economic Activity, American Economic Review 86 (1), 54-70.

Ciccone, A., 2002, Agglomeration effects in Europe, European Economic Review 46, 213-227.

Coase, R. H., 1937, The Nature of the Firm, Economica 4, 386-405.

Combes, P.P., 2000, Economic Structure and Local Growth: France, 1984-1993, Journal of Urban Economics 47: 329-355.

Deardorff,-A.V. and S. Djankov, 2000, Knowledge Transfer under Subcontracting: Evidence from Czech Firms, World Development 28(10), 1837-47.

European-Commission, 1997, New industrial subcontracting in Europe, First results with an updated definition, Luxembourg.

Fariñas, J.C. and J. Jaumandreu, 1999, Diez años de Encuesta sobre Estrategias Empresariales, Economía Industrial 329, 29-42.

Girma, S. and H. Görg, 2004, Outsourcing, foreign ownership and productivity: Evidence from UK establishment level data, Review of International Economics, 12(5), 817-832.

Görg, H. and F. Ruane, 2000, An Analysis of Backward Linkages in the Irish Electronics Sector, The Economic and Social Review 31 (3), 215-235.

Görzig B. and A. Stephan, 2002, Outsourcing and firm-level performance, Discussion Paper No. 309, DIW Berlin.

Grossman, G. M. and E. Helpman, 2002, Integration versus outsourcing in industry equilibrium, The Quarterly Journal of Economics 117(1), 85120.

Grossman, G. M. and E. Helpman, 2005, Outsourcing in a global economy, Review of Economic Studies 90, 1239-1254.

Grossman, S. J. and O. D. Hart, 1986, The Costs and Benefits of Ownership: A Theory of Vertical and Lateral Integration, Journal of Political Economy 94, 691-719.

Helsley, R. W. and W. C. Strange, 2007, Agglomeration, Opportunism, and the Organisation of Production, Journal of Urban Economics, forthcoming. 
Helsley, R.W. and W. C. Strange, 2002, Innovation and Input Sharing, Journal of Urban Economics 51(1), 25-45.

Holmes, J., 1986, The Organisation and Locational Structure of Production Subcontracting”, in A.J. Scott and M. Storper (eds.), Production, Work, and Territory: The Geographical Anatomy of Industrial Capitalism. Boston: Allen \& Unwin, pp. 80-106.

Holmes, J. T., 1999, Localisation of Industry and Vertical Disintegration, Review of Economics and Statistics 81(2), 314-325.

Kelley, M. R. and B. Harrison, 1990, The Subcontracting Behaviour of Single vs. Multiplant Enterprise in US Manufacturing: Implications for Economic Development, World Development 18 (9), 1273-1294.

Love, H. J. and S. Roper, 2001, Outsourcing in the innovation process: Locational and strategic determinants, Papers in Regional Science 80, 317-336.

Marshall, A., 1920, Principles of Economics. 8th edition. London: Macmillan.

Mazzola, F. and S. Bruni, 2000, The role of linkages in firm performance: evidence from southern Italy, Journal of Economic Behaviour and Organisation 43, 199-221.

Merino, F. and Rodríguez, D., 2005, Business Service Outsourcing by Manufacturing Firms, Real Collegio Complutense Working Paper 04/05.

Ministry of Industry, 1992, Un Panorama de la Industria Española, Madrid.

Morrison Paul, C. J. and M. Yasar, 2004, Outsourcing, Productivity, and Input Composition at the Plant Level, Working paper, University of Califorina, Davis.

Nocke, V., 2006, A gap for me: Entrepreneurs and Entry, Journal of the European Economic Association 4 (5): 929-956.

Ono, Y., 2007, Outsourcing business services and the scope of local markets, Regional Science and Urban Economics 37 (2), 220-238.

Ono, Y., 2003, Outsourcing business services and the role of central administrative offices, Journal of Urban Economics 53, 377-395.

Rama, R., D. Ferguson and A. Melero, 2003, Subcontracting Networks in Industrial Districts: The Electronics Industries of Madrid, Regional Studies 37 (1), 71-88.

Roodhooft, F. and L. Warlop, 1999, On the role of sunk costs and asset specificity in outsourcing decisions: a research note, Accounting, Organizations and Society 24, 363-369.

Rosenthal, S. S. and W. C. Strange, 2003, Geography, Industrial Organisation, and Agglomeration, Review of Economics and Statistics 85, 377-393.

Rosenthal, S. S. and W. C. Strange, 2004, Evidence on the Nature and Sources of Agglomeration Economies, in the Handbook of Urban and Regional Economics, Volume 4, eds. Vernon Henderson and Jacques Thisse. Amsterdam: North-Holland. 
Scott A. J, 1987, Industrial organisation and location: divisions of labour, the firm and spatial process, Economic Geography 63, 215-231.

Scott, A. J., 1988, New industrial spaces: Flexible Production, Organisation and Regional Development in North America and Western Europe. Pion. London.

Scott, A. J., 1993, Interregional Subcontracting Patterns in the Aerospace Industry: The Southern California Nexus, Economic Geography 69 (2), 142-156.

Shy, O. and R. Stenbacka, 2003, Strategic outsourcing, Journal of Economic Behavior and Organization 50: 203-224.

Stigler, G. J., 1951, The Division of Labor is Limited by the Extent of the Market, Journal of Political Economy 59 (3), 185-193.

Suarez-Villa, L. and R. Rama, 1996, Outsourcing, R\&D and the Pattern of Intrametropolitan-Location: The Electronics Industries of Madrid, Urban Studies 33 (7), 1155-1197.

Taymaz, E. and Y. Kilicaslan, 2005, Determinants of Subcontracting and Regional Development: An Empirical Study on Turkish Textile and Engineering Industries, Regional Studies 39 (5), 633-645.

Urata, S. and H. Kawai, 2002, Technological Progress by Small and Medium Enterprises in Japan, Small Business Economics 18, 53-67.

Venables, A., 1996, Equilibrium locations of vertically linked industries, International Economic Review 37, 341-359.

Williamson, O. E., 1975, Markets and Hierarchies: Analysis and Antitrust Implications, New York: Free Press.

Williamson, O. E., 1985, The Economic Institutions of Capitalism, New York: Free Press.

Wooldridge, J., 2002. Econometric Analysis of Cross Section and Panel Data. MIT Press. 
Table 1. Production subcontracting by firm size

\begin{tabular}{|c|c|c|c|c|c|c|}
\hline & \multicolumn{2}{|c|}{ Number of Firms } & \multicolumn{2}{|c|}{$\begin{array}{l}\text { Percentage of firms } \\
\text { that subcontract }\end{array}$} & \multicolumn{2}{|c|}{$\begin{array}{c}\text { Share of } \\
\text { subcontracting in } \\
\text { total purchased inpu }\end{array}$} \\
\hline & 1990 & 1999 & 1990 & 1999 & 1990 & 1999 \\
\hline All manufacturing firms & 2096 & 1522 & 35.6 & 43.4 & 7.5 & 9.7 \\
\hline $\begin{array}{l}\text { Small (less than } 25 \\
\text { employees) }\end{array}$ & 775 & 457 & 24.5 & 36.6 & 6.3 & 8.8 \\
\hline $\begin{array}{l}\text { Medium (between } 25 \text { and } 200 \\
\text { employees) }\end{array}$ & 642 & 631 & 36.0 & 39.8 & 7.7 & 9.8 \\
\hline $\begin{array}{l}\text { Large (more than } 200 \\
\text { employees) }\end{array}$ & 696 & 415 & 47.5 & 56.3 & 8.9 & 10.5 \\
\hline Source: ESEE & & & & & & \\
\hline
\end{tabular}

Table 2. Production subcontracting by industry sector

\begin{tabular}{lrrrr}
\hline & $\begin{array}{r}\text { Percentage of firms that } \\
\text { subcontract }\end{array}$ & \multicolumn{2}{c}{$\begin{array}{c}\text { Share of subcontracting in total } \\
\text { purchased input }\end{array}$} \\
Sector & 1990 & 1999 & 1990 & 1999 \\
\hline Metals & 17.4 & 30.0 & 0.4 & 3.9 \\
Mineral products & 21.0 & 27.1 & 4.9 & 5.3 \\
Chemical products & 31.5 & 33.3 & 2.8 & 4.1 \\
Metal products & 42.6 & 36.0 & 8.6 & 9.4 \\
Industrial \& Agric. machinery & 58.9 & 69.9 & 16.5 & 19.8 \\
Office equipment & 54.5 & 41.2 & 10.3 & 8.8 \\
Electrical equipment & 47.4 & 62.0 & 10.7 & 13.4 \\
Motor vehicles and motors & 51.2 & 58.8 & 13.4 & 13.2 \\
Other transport equipment & 46.2 & 69.7 & 14.8 & 20.8 \\
Meat products & 10.5 & 22.0 & 0.6 & 2.3 \\
Other food \& tobacco & 22.4 & 23.8 & 3.2 & 3.4 \\
Drinks & 17.4 & 13.0 & 4.2 & 3.3 \\
Textile and clothing & 34.3 & 53.2 & 6.9 & 14.7 \\
Leather and shoes & 26.5 & 31.3 & 3.9 & 5.6 \\
Wood and furniture & 30.2 & 38.5 & 7.4 & 8.3 \\
Paper and printing & 38.4 & 51.3 & 8.5 & 13.9 \\
Plastic and rubber products & 35.1 & 46.9 & 7.4 & 7.2 \\
Other manufacturing & 56.8 & 45.5 & 15.8 & 5.5 \\
\hline Data Source: ESEE & & & & \\
\hline
\end{tabular}


Table 3. Production subcontracting by NUTS 1 Region

\begin{tabular}{llllll}
\hline & \multicolumn{3}{c}{$\begin{array}{c}\text { Percentage of firms that } \\
\text { subcontract }\end{array}$} & \multicolumn{3}{c}{$\begin{array}{c}\text { Share of subcontracting in total } \\
\text { purchased input }\end{array}$} \\
NUTS 1 - regions & 1990 & 1999 & \multicolumn{2}{c}{1990} & 1999 \\
\hline Industrial core-areas & & & 7.8 & 10.5 \\
ES5 $\quad$ East & 38.8 & 46.8 & 8.9 & 11.7 \\
ES2 North-East & 40.2 & 45.0 & 8.9 & 9.9 \\
ES3 Madrid & 40.4 & 46.8 & & \\
Periphery & & & 5.9 & 8.1 \\
ES1 North-West & 28.6 & 42.9 & 5.8 & 7.3 \\
ES4 Centre & 23.7 & 33.8 & 5.8 & 7.5 \\
ES6 South & 26.2 & 31.5 & & \\
\hline Data Source: ESEE & & & & \\
\hline
\end{tabular}


Table 4. Determinants of the decision to subcontract

\begin{tabular}{|c|c|c|c|c|c|}
\hline & \multicolumn{3}{|c|}{ Probit } & \multirow{2}{*}{$\begin{array}{c}\text { RE probit } \\
(4)\end{array}$} & \multirow{2}{*}{$\begin{array}{c}\text { CRE probit } \\
(5)\end{array}$} \\
\hline & (1) & $(2)$ & (3) & & \\
\hline \multirow[t]{2}{*}{ WAGE } & $0.255^{*}$ & $0.255^{*}$ & $0.244 *$ & $0.326 *$ & $0.270 * * *$ \\
\hline & $(0.032)$ & $(0.032)$ & $(0.061)$ & $(0.121)$ & $(0.149)$ \\
\hline \multirow[t]{2}{*}{ SIZE } & $0.110^{*}$ & $0.119^{*}$ & $0.159 *$ & $0.257^{*}$ & $0.274 * *$ \\
\hline & $(0.009)$ & $(0.009)$ & $(0.021)$ & $(0.052)$ & $(0.119)$ \\
\hline \multirow[t]{2}{*}{ SMALLP } & & $0.117^{*}$ & $0.206^{*}$ & $0.224 * *$ & 0.119 \\
\hline & & $(0.023)$ & $(0.053)$ & $(0.105)$ & $(0.126)$ \\
\hline \multirow[t]{2}{*}{ AGE } & 0.048* & $0.050^{*}$ & $0.102^{*}$ & $0.153 *$ & $0.118^{* * *}$ \\
\hline & $(0.012)$ & $(0.012)$ & $(0.027)$ & $(0.060)$ & $(0.067)$ \\
\hline \multirow[t]{2}{*}{ FORD } & $-0.085^{*}$ & $-0.082 *$ & $-0.190 *$ & -0.052 & 0.273 \\
\hline & $(0.030)$ & $(0.029)$ & $(0.072)$ & $(0.161)$ & $(0.214)$ \\
\hline \multirow[t]{2}{*}{ FLUCT } & $0.131^{*}$ & $0.131^{*}$ & 0.080 & -0.092 & -0.123 \\
\hline & $(0.023)$ & $(0.023)$ & $(0.054)$ & $(0.081)$ & $(0.085)$ \\
\hline \multirow[t]{2}{*}{ IND } & $0.070^{*}$ & $0.072^{*}$ & $0.206^{*}$ & $0.352 *$ & $1.104^{* *}$ \\
\hline & (0.009) & $(0.010)$ & $(0.038)$ & $(0.095)$ & $(0.476)$ \\
\hline \multirow[t]{2}{*}{ IND*WAGE } & & & 0.002 & -0.049 & $-0.110^{* *}$ \\
\hline & & & $(0.024)$ & $(0.047)$ & $(0.057)$ \\
\hline \multirow[t]{2}{*}{ IND*SIZE } & & & $-0.017 * *$ & -0.021 & $-0.089 * *$ \\
\hline & & & $(0.008)$ & $(0.020)$ & $(0.045)$ \\
\hline \multirow[t]{2}{*}{ IND*AGE } & & & $-0.022^{* *}$ & -0.031 & -0.183 \\
\hline & & & $(0.011)$ & $(0.023)$ & (0.129) \\
\hline \multirow[t]{2}{*}{ IND*FORD } & & & $0.045^{* * *}$ & 0.003 & -0.099 \\
\hline & & & $(0.027)$ & $(0.059)$ & $(0.080)$ \\
\hline \multirow[t]{2}{*}{ IND*SMALLP } & & & $-0.037 * * *$ & $-0.069 * * *$ & -0.063 \\
\hline & & & $(0.020)$ & $(0.040)$ & $(0.050)$ \\
\hline IND*FLUCT & & & $\begin{array}{c}0.022 \\
(0.017) \\
\end{array}$ & $\begin{array}{l}0.064 * * \\
(0.031) \\
\end{array}$ & $\begin{array}{l}0.058 * * * \\
(0.033)\end{array}$ \\
\hline Observations & 16519 & 16234 & 16234 & 16234 & 16234 \\
\hline Log likelihood & -10292.26 & -10109.51 & -10100.82 & -7823.62 & -7791.27 \\
\hline LR test $(\mathrm{rho}=0)$ & & & & $4554.41^{*}$ & 4518.58* \\
\hline
\end{tabular}


Figure 1: Marginal effect of industry density at various levels of firm size

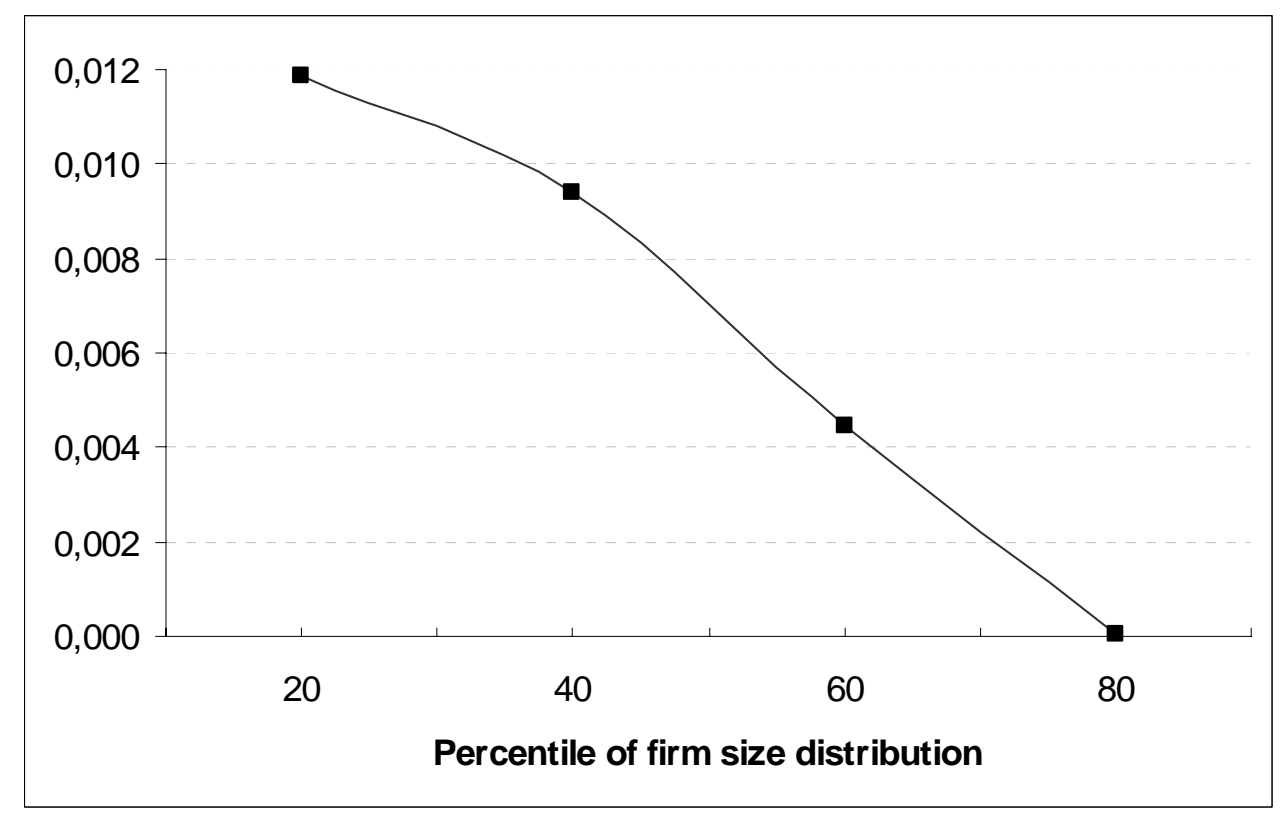

Figure 2: Marginal effect of industry density at various wage levels

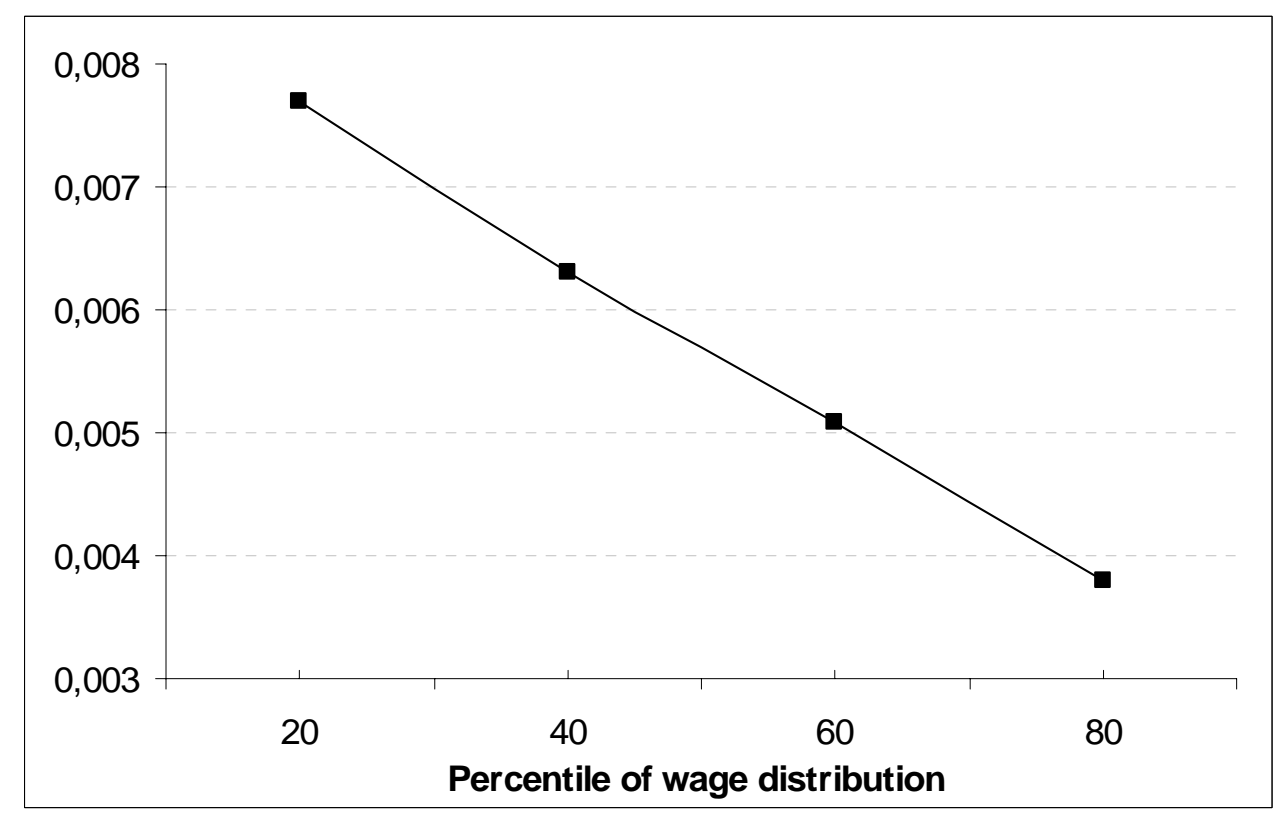


Table A1. Sample detail

\begin{tabular}{cccc}
\hline Number of Years & Number of Firms & Number of Observations \\
\hline 1 & 105 & 105 \\
& 234 & 468 \\
3 & 532 & 1,596 \\
& 310 & 1,240 \\
& 5 & 206 & 1,030 \\
6 & 177 & 1,062 \\
& 7 & 181 & 1,267 \\
& 8 & 132 & 1,056 \\
& 9 & 170 & 1,530 \\
\hline Total & 10 & 688 & 6,880 \\
\hline
\end{tabular}

Table A2: Characteristics of subcontractors and non-subcontractors

\begin{tabular}{|c|c|c|c|c|}
\hline & \multicolumn{2}{|c|}{ High agglomeration } & \multicolumn{2}{|c|}{ Low agglomeration } \\
\hline & Subcontractors & $\begin{array}{c}\text { Non- } \\
\text { subcontractors }\end{array}$ & Subcontractors & $\frac{\text { Non- }}{\text { subcontractors }}$ \\
\hline & $48,0 \%$ & $52,0 \%$ & $35,5 \%$ & $64,5 \%$ \\
\hline & mean & mean & mean & mean \\
\hline WAGE & 0.73 & $0.61 *$ & 0.57 & $0.39 *$ \\
\hline SIZE & 4.49 & $4.06 *$ & 4.66 & $3.94 *$ \\
\hline AGE & 2.85 & $2.69 *$ & 2.68 & $2.46 *$ \\
\hline FLUCT & 0,33 & 0,28 * & 0,34 & $0,28 *$ \\
\hline FORD & 0,27 & 0,22 * & 0,24 & 0,16 * \\
\hline SMALLP & 0,56 & 0,54 * & 0,58 & 0,53 * \\
\hline
\end{tabular}


Table A3: Correlation matrix

\begin{tabular}{lrrrrrrrr}
\hline & SUBC & LWAGE & LSIZE & LAGE & FLUCT & FORD SMALLP & IND \\
\hline & & & & & & & & \\
SUBC & 1,000 & & & & & & & \\
LWAGE & 0,165 & 1,000 & & & & & & \\
LSIZE & 0,169 & 0,464 & 1,000 & & & & & \\
LAGE & 0,098 & 0,390 & 0,437 & 1,000 & & & \\
FLUCT & 0,054 & 0,036 & 0,101 & $-0,024$ & 1,000 & & \\
FORD & 0,085 & 0,397 & 0,491 & 0,210 & 0,063 & 1,000 & & \\
SMALLP & 0,034 & $-0,147$ & $-0,310$ & $-0,149$ & $-0,044$ & $-0,193$ & 1,000 & \\
IND & 0,133 & 0,266 & 0,070 & 0,138 & 0,014 & 0,085 & 0,006 & 1,000 \\
\hline
\end{tabular}

